\title{
Maintenance and Rehabilitation Prioritization of School Buildings Using Knapsack Problem
}

\author{
Muhammad Abu Thohir, Senot Sangadji, Sholihin As'ad ${ }^{1)}$ \\ Civil Engineering MPRI Universitas Negeri Sebelas Maret Surakarta, \\ Jl. Ir. Sutami 36A Kentingan Jebres Surakarta 57126, INDONESIA \\ E-mail: muhammad.abu@student.uns.ac.id, s.sangadji@ft.uns.ac.id, \\ sholihinasad@staff.uns.ac.id
}

\begin{abstract}
Many of the public buildings are in conditions of distress due to deterioration and damage and require maintenance and rehabilitation to be able to function appropriately. On the contrary the government funding and budget allocated is limited. A systematic approach to overcome the problem is using setting up priority and optimize the resources allocation. Within a budget ceiling the what buildings components should be prioritized to achieve maximum profit and or surpass threshold is the ultimate goal of the decision maker and stakeholders. In this study, optimizing budget allocated for maintenance and rehabilitation of building components may be carried out by implementing knapsack algorithm within dynamic programming framework. The public junior high school 4 (SMPN 4) building was chosen as case study to apply the algorithm and determine the priority scale. The building is in Salatiga and suffers from some material deterioration as well as structural component degradation. The school building consists of three main sections namely, building itself, school yard, and school fence. To assess and evaluate damage based on the criteria set by Ministry of National Education, the building is divide into structures, architecture, and utilities. These components were divided into elements and sub elements. The structure was divided into the roof structure, super structure above the ground, and substructure (foundation). The damage condition of components and sub components of the building was then tabulated by assigning weights according to criteria set by office of education of Salatiga (Dinas Pendidikan Kota Salatiga, 2017).
\end{abstract}

\section{INTRODUCTION}

The entire life cycle of a building include construction, operation, maintenance, demolition and removal (Chan, 2014). As a place for hundreds of children and young adolescents carrying out their activities every day, school building shall function properly, reliably and comfortably providing space and conducive environments and protecting them from harmful surroundings. Building maintenance is the key to keeping the quality of the buildings. The main factors that inhibit are the limited budget. Therefore, school manager should make a right decision in performing maintenance activities within the financial constraints. The decision may involve prioritization and scheduling to have maintenance right on target. Regarding maintenance and rehabilitation of buildings, several criteria that may be used as consideration for the school manager in making decisions. Two of them are; (1) the extent of damage and (2) the cost of rehabilitation. Considering these criteria and the limited budget, the school 
manager must prioritize the building components for budget allocation. The aim of this research is to optimize the decision in school buildings maintenance and rehabilitation. Dynamic programming employed in this study offers a mathematical framework to optimize decision under several uncertain phases. The results of and techniques presented in this study are expected to be a reference for building manager of the school to choose alternative components for maintenance activities in the school building.

\section{METHODOLOGY}

Maintenance and rehabilitation prioritization of school buildings may be represented mathematically as one of the problems of knapsack $0 / 1$ because the situation of the decision maker is required to choose the components of the school building will be carried out maintenance and left behind for maintenance in the next year. So the choice is taken between yes or no.

\subsection{Knapsack Problem}

The knapsack problem is a combinatorial optimization problem where a set of each item have weights and value. The weight and the value of each item determine the amount to be included in the collection therefore that the total weight is less than or equal to the weight and the total value of all possible. According Toth (1979), knapsack problem can be formulated as 0/1 Knapsack Problem formulation:

$$
\begin{gathered}
\text { Maximize } P=\sum_{i=1}^{n} C i X i \\
\text { Subject to } \sum_{i=1}^{n} W i X i \leq W
\end{gathered}
$$

Where:

$\mathrm{Ci}=$ benefit from alternative

$\mathrm{Wi}=$ cost for alternative

The formulation of knapsack problem 0-1 limiting the possibility of choice taken between 1 or 0 .

\subsection{Knapsack problem by dynamic programming}

Knapsack Problem 0-1 can be solved by mathematical equations of dynamic programming. According Klamroth and Wiecek, dynamic programming being a very exible technique, is a unifying umbrella under which all variations can be solved. The case of building maintenance is a deterministic dynamic programming category. Deterministic issues are the state at the next stage is entirely determined by the state and the decision at the current stage. To categorize this deterministic dynamic programming problems is by looking at the objective function. The prioritization of the school building aims to get the maximum value of the improvements that were made to the building components are selected. So the solution steps are as follows: 
a. The problem is divided into stages with a decision at each stage.

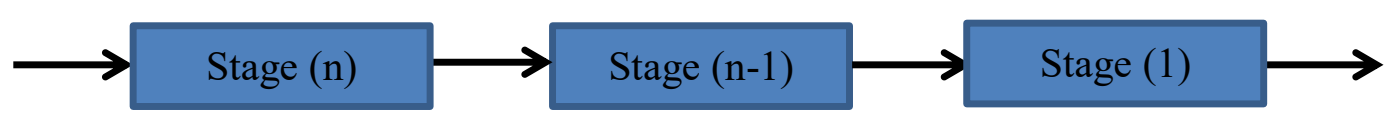

Figure 2.1. The division of the problem into several stages

b. Each stage has a state that is associated with the stage. The status of the input is a variety of possibilities that exist on a particular system. On a matter with n-stage, there are two inputs: the state in the step-n $(\mathrm{Sn})$ and decision variable $(\mathrm{Xn})$. The output is return or result of $\mathrm{Xn}$ that selected fn $(\mathrm{S}, \mathrm{Xn})$ and a new state is input at a next stage (Sn-1). The relation between $\mathrm{Xn}$ and $\mathrm{fn}(\mathrm{S}, \mathrm{Xn})$ is determined by the return function. The relations between state at a stage is according to the transition function.

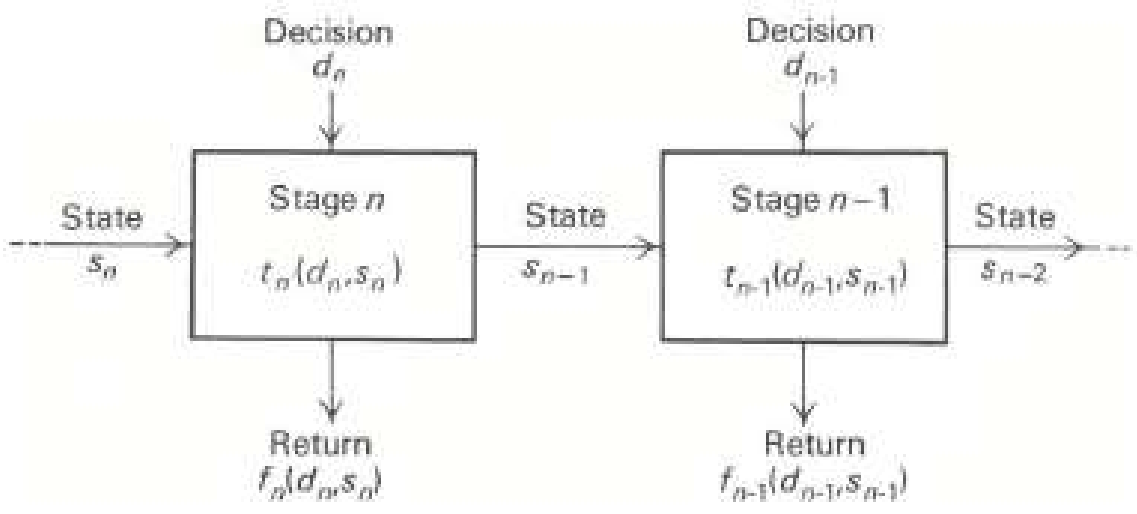

Figure 2.2. Relationship between status at a certain stage (http://web.mit.edu/15.053/www/AMP-Chapter-11)

c. The decision of each stage are the decisions that can be selected for a stage.

d. The optimal solution of the dynamic programming problem is the same as the decision on the status selection from the last stage.

e. The recursive relationship that identifies the optimal choice for each state at stage $n$, provides an optimal choice for each state at stage $n+1$.

The form of its recursive function is:

$$
\mathrm{f}_{\mathrm{n}}\left(\mathrm{S}_{\mathrm{n}}\right) \quad=\max \left\{\mathrm{f}_{\mathrm{n}}\left(\mathrm{S}_{\mathrm{n}}, \mathrm{X}_{\mathrm{n}}\right)\right\}
$$

$$
\text { Subject to } \sum_{i=1}^{n} \mathrm{Sn}, \mathrm{Xn} \leq W, \quad X i \in\{0 \mid 1\}
$$

Where:

$\mathrm{fn}(\mathrm{Sn}) \quad=$ The optimal result of the decision at the stage $\mathrm{n}$

$\mathrm{W} \quad$ = budget

\section{RESULT AND DISCUSSION}

\subsection{Inventory of School Building (SMP Negeri 4 Salatiga)}

SMP Negeri 4 Salatiga is located at $47^{\text {th }}$ Pattimura Street Salatiga. The buildings stand on the area of $4755 \mathrm{~m}^{2}$ owned by the municipal government of Salatiga. At the school, there is forty space is divided to seven building where two of them is two floors building and five one floor buildings. The site plan of SMP Negeri 4 Salatiga can be seen in Figure 3.1. 


\subsection{Analysis of Building Damage}

The school building consists of 3 main sections namely, building itself, school yard, and school fence. To assess and evaluate the damage, the building is divide into structure, architecture, and utilitiy components. These components were then divided into elements and sub elements. The structure is divided into the roof structure, super structure above the ground, and substructure (foundation). To determine the calculation of school buildings damage, must be obtained the weight of each sub-buildings, components, elements, and sub-elements in school buildings. The weight of each subschool building by Sutikno (2009) is shown in Table 1.

Tabel 1. Weight of sub-school buildings

\begin{tabular}{ccc}
\hline No & Sub Building & Weight (\%) \\
\hline 1 & Building & 73,35 \\
2 & School fence & 18,79 \\
3 & School yard & 7,86 \\
\hline Total & & $\mathbf{1 0 0}$ \\
\hline
\end{tabular}

Source: Sutikno (2009)

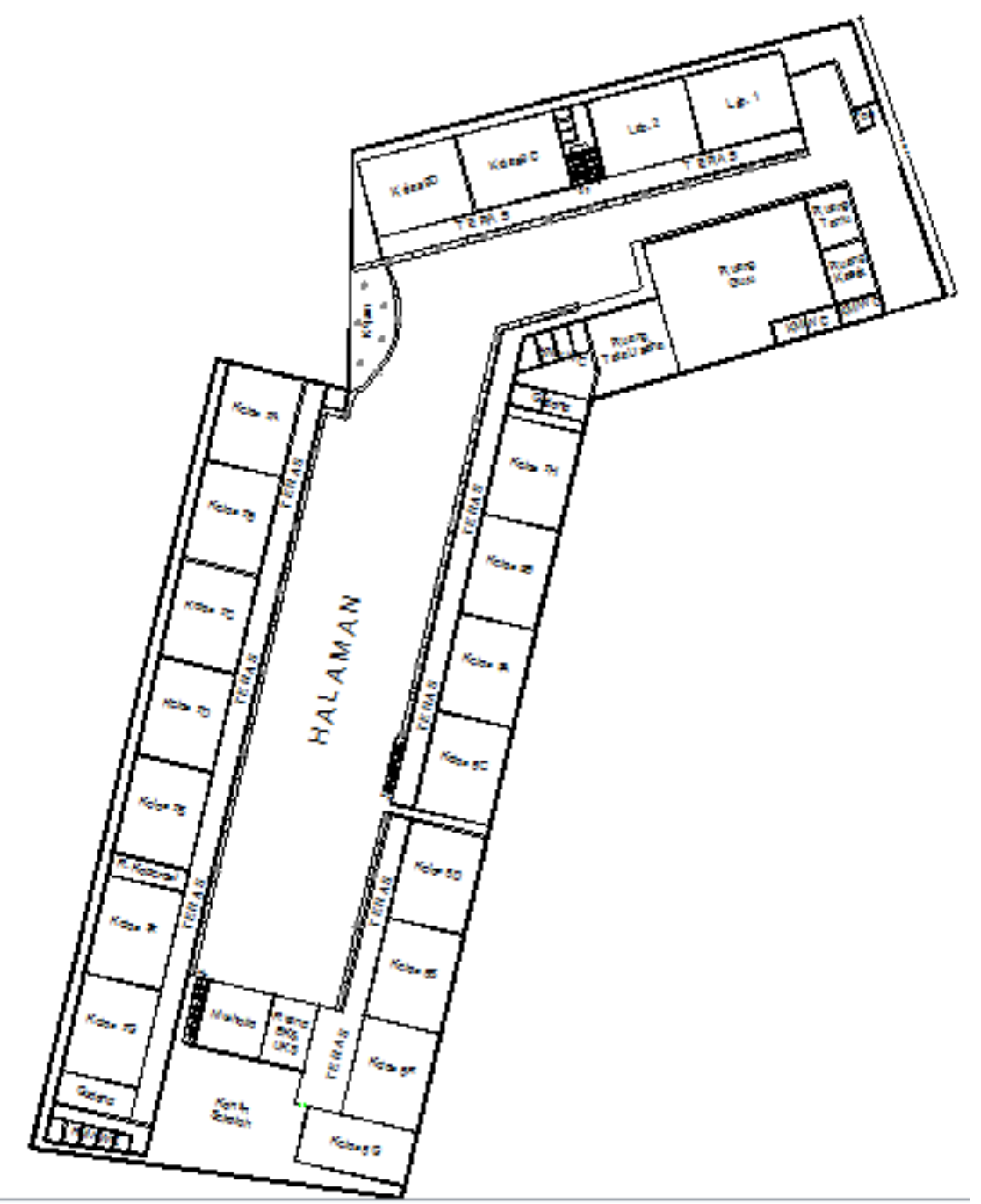

Figure 3.1. Siteplan of SMP Negeri 4 Salatiga 
The damage condition of components and sub components of the building was then tabulated by assigning weights according to criteria set by the office of education of the city of Salatiga (Dinas Pendidikan Kota Salatiga, 2017) as shown in Table 2. Afterward, the damage condition of each component, element and sub-element were obtained by visual inspection appears in Table 3. The table recapitulates the volume of the damage.

Tabel 2. Weight of School Building Components

\begin{tabular}{lllr}
\hline No & \multicolumn{1}{c}{$\begin{array}{c}\text { Building } \\
\text { Component }\end{array}$} & \multicolumn{1}{c}{ Sub Building Component } & Weight(\%) \\
\hline 1 & Roof & Roofing & 10,56 \\
& & Roof Frame & 11,62 \\
& & Lis sign \& chamfer & 2,06 \\
2 & \multirow{2}{*}{ Ceiling } & Order ceiling & 4,67 \\
& & Cover \&lis ceiling & 5,06 \\
& & Paint & 1,41 \\
3 & \multirow{2}{*}{ Wall } & ring beams and Columns & 9,66 \\
& & Brick/wall charger & 13,68 \\
& & Paint & 1,65 \\
\hline 4 & Door \& Window & Sills & 2,70 \\
& & Door & 2,47 \\
& & Window & 5,15 \\
5 & \multirow{2}{*}{ Floor } & Structure & 2,89 \\
& & Floor covering & 8,96 \\
6 & \multirow{2}{*}{ Foundation } & The Foundation & 11,15 \\
& & Foundation beam & 3,30 \\
7 & Utilities & Electrical & 1,79 \\
& & Installation of rain water \& couples traveling & 1,22 \\
& & concrete building rebates & $\mathbf{1 0 0}$
\end{tabular}

Source: Dinas Pendidikan Kota Salatiga (2017)

In this study, the observed was limited by the building components. Type of damage experienced by SMP Negeri 4 Salatiga, among others rotted wooden material, cracks and ruptures on the concrete material, and loose on and ceramics plastic material. And among the building components where have damage the most is a components made of wood. 

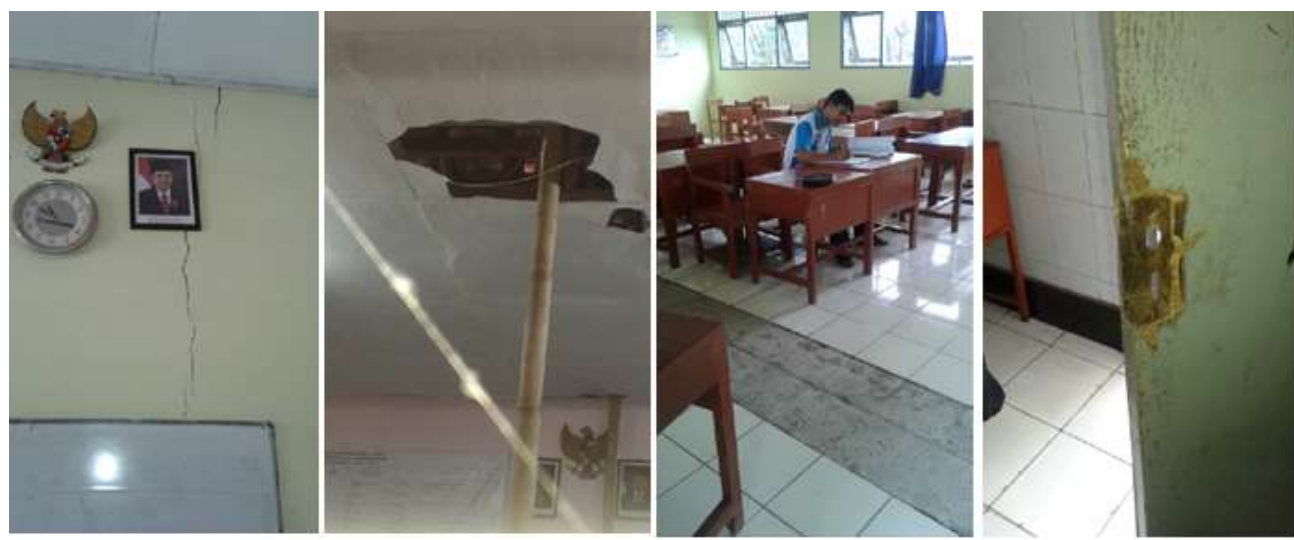

Figure 3.2. Damage of SMP Negeri 4 Salatiga

Inventorying damage was done by inspecting each of the components of the building visually. The observations are then recorded on the chart referring to the regulation of the Minister of education and culture Number 57 in 2011, where the volume of damage are distinguished into three kinds, namely based on length (gutter, foundation, foundation beams, installation of rainwater \& pedestrian walk in the perimeter of the buildings), based on surface area (roofing, roof frame, the frame of the plafond, cover and list of ceiling, paint of ceiling, brick/wall filler, paint of wall the, structure of the floors, and floor covering), and based on the number of units (column and lintel, sills, doors, shutters, and electrical installation). Afterward, the damage condition of principal's office, elements and sub element were obtained by visual inspection as shown in table 3 . The table recapitulates the volume of damage of the components.

Table 3. Volume of damage of principal's office

\begin{tabular}{|c|c|c|c|c|c|c|}
\hline No & $\begin{array}{c}\text { Building } \\
\text { Component }\end{array}$ & $\begin{array}{c}\text { Sub Building } \\
\text { Component }\end{array}$ & $\begin{array}{c}\text { Total } \\
\text { Volum } \\
\text { e }\end{array}$ & Unit & $\begin{array}{c}\text { Volume Of } \\
\text { Damage }\end{array}$ & $\begin{array}{c}\text { Damage } \\
(\%)\end{array}$ \\
\hline \multirow[t]{3}{*}{1} & Roof & Roofing & 30 & $\mathrm{~m}^{2}$ & 0 & 0.00 \\
\hline & & Roof Frame & 30 & $\mathrm{~m}^{2}$ & 0 & 0.00 \\
\hline & & Roof gutter & 10 & $\mathrm{~m}^{2}$ & 10 & 100.00 \\
\hline \multirow[t]{3}{*}{2} & Ceiling & Frame of ceiling & 24 & $\mathrm{~m}^{2}$ & 0 & 0.00 \\
\hline & & Ceiling cover & 24 & $\mathrm{~m}^{2}$ & 0 & 0.00 \\
\hline & & Paint & 24 & $\mathrm{~m}^{2}$ & 24 & 100.00 \\
\hline \multirow[t]{3}{*}{3} & Wall & Lintel and Columns & 10 & piece & 0 & 0.00 \\
\hline & & Brick Masonry wall & 80 & $\mathrm{~m}^{2}$ & 0 & 0.00 \\
\hline & & Paint & 160 & $\mathrm{~m}^{2}$ & 80 & 50.00 \\
\hline \multirow[t]{3}{*}{4} & Door \& & Sills & 3 & piece & 0 & 0.00 \\
\hline & Window & Door & 2 & piece & 0 & 0.00 \\
\hline & & Windows & 2 & piece & 0 & 0.00 \\
\hline \multirow[t]{2}{*}{5} & Floor & Structure & 24 & $\mathrm{~m}^{2}$ & 0 & 0.00 \\
\hline & & Floor cover & 24 & $\mathrm{~m}^{2}$ & 0 & 0.00 \\
\hline 6 & Foundation & The Foundation & 20 & $\mathrm{~m}$ & 0 & 0.00 \\
\hline
\end{tabular}




\begin{tabular}{|c|c|c|c|c|c|c|}
\hline No & $\begin{array}{c}\text { Building } \\
\text { Component }\end{array}$ & $\begin{array}{c}\text { Sub Building } \\
\text { Component }\end{array}$ & $\begin{array}{c}\text { Total } \\
\text { Volum } \\
\text { e }\end{array}$ & Unit & $\begin{array}{c}\text { Volume Of } \\
\text { Damage }\end{array}$ & $\begin{array}{c}\text { Damage } \\
(\%)\end{array}$ \\
\hline \multirow{3}{*}{7} & \multirow{3}{*}{ Utilities } & Foundation beam & 20 & $\mathrm{~m}$ & 0 & 0.00 \\
\hline & & Electrical & 12 & piece & 0 & 0.00 \\
\hline & & $\begin{array}{l}\text { Installation of rain } \\
\text { water \&pedestrian } \\
\text { walk in the perimeter } \\
\text { of the buildings }\end{array}$ & 6 & $\mathrm{~m}^{2}$ & 0 & 0.00 \\
\hline
\end{tabular}

Source: analysis results

While the percentage level of damage to the principal's office can be seen in table 4 as the following:

Table 4. Analysis of damage level of principal's office

\begin{tabular}{|c|c|c|c|c|c|c|}
\hline \multirow[b]{2}{*}{$\begin{array}{l}\mathbf{N} \\
\mathbf{0}\end{array}$} & \multirow[b]{2}{*}{$\begin{array}{c}\text { Building } \\
\text { Component }\end{array}$} & \multirow[b]{2}{*}{$\begin{array}{l}\text { Sub Building } \\
\text { Component }\end{array}$} & \multicolumn{2}{|c|}{ Weight(\%) } & \multicolumn{2}{|c|}{ Damage Level } \\
\hline & & & $\begin{array}{l}\text { Against } \\
\text { the Entire } \\
\text { Building }\end{array}$ & $\begin{array}{l}\text { Maximu } \\
\text { m } \\
\text { Damage }\end{array}$ & $\begin{array}{c}\text { Weight } \\
(\%)\end{array}$ & $\begin{array}{c}\text { Procentag } \\
\text { e }(\%)\end{array}$ \\
\hline \multirow[t]{3}{*}{1} & \multirow[t]{3}{*}{ Roof } & Roofing & 10,56 & 100 & 0.00 & 0.00 \\
\hline & & Roof Frame & 11,62 & 100 & 0.00 & 0.00 \\
\hline & & Roof gutter & 2,06 & 100 & 100.00 & 2.06 \\
\hline \multirow[t]{3}{*}{2} & \multirow[t]{3}{*}{ Ceiling } & Frame of ceiling & 4,67 & 100 & 0.00 & 0.00 \\
\hline & & Ceiling cover & 5,06 & 100 & 0.00 & 0.00 \\
\hline & & Paint & 1,41 & 100 & 100.00 & 1.41 \\
\hline \multirow[t]{3}{*}{3} & \multirow[t]{3}{*}{ Wall } & Lintel and Columns & 9,66 & 100 & 0.00 & 0.00 \\
\hline & & Brick Masonry wall & 13,68 & 100 & 0.00 & 0.00 \\
\hline & & Paint & 1,65 & 100 & 50.00 & 0.83 \\
\hline \multirow[t]{3}{*}{4} & \multirow{3}{*}{$\begin{array}{l}\text { Door \& } \\
\text { Window }\end{array}$} & Sills & 2,70 & 100 & 0.00 & 0.00 \\
\hline & & Door & 2,47 & 100 & 0.00 & 0.00 \\
\hline & & Windows & 5,15 & 100 & 0.00 & 0.00 \\
\hline \multirow[t]{2}{*}{5} & \multirow[t]{2}{*}{ Floor } & Structure & 2,89 & 100 & 0.00 & 0.00 \\
\hline & & Floor cover & 8,96 & 100 & 0.00 & 0.00 \\
\hline \multirow[t]{2}{*}{6} & \multirow[t]{2}{*}{ Foundation } & The Foundation & 11,15 & 100 & 0.00 & 0.00 \\
\hline & & Foundation beam & 3,30 & 100 & 0.00 & 0.00 \\
\hline \multirow[t]{2}{*}{7} & \multirow[t]{2}{*}{ Utilities } & Electrical & 1,79 & 100 & 0.00 & 0.00 \\
\hline & & $\begin{array}{l}\text { Installation of rain } \\
\text { water \&pedestrian } \\
\text { walk in the perimeter } \\
\text { of the buildings }\end{array}$ & 1,22 & 100 & 0.00 & 0.00 \\
\hline
\end{tabular}

Source: analysis results 
The analysis is continued as the stages above for the entire room that exists in SMP Negeri 4 Salatiga. The results of the analysis for each room was grouped into simpler spaces into the level of damage to building components. So, it is obtained the degree of damage to the components of the roof, plafond, walls, doors and windows, floors, foundation, and utilities. From the results of the analysis, it brings that sub component that having damage the most is windows and doors with the rate $2.70 \%$ of damage. While the sub components are most excellent condition is a foundation with a value of $0 \%$, or the extent of damage suffered no damage. The observations can be seen in table 5.

Table 5. Level Damage of Building Component of SMP Negeri 4 Salatiga

\begin{tabular}{llc}
\hline No & \multicolumn{1}{c}{$\begin{array}{c}\text { Building } \\
\text { Components }\end{array}$} & $\begin{array}{c}\text { Rating of Damage } \\
(\%)\end{array}$ \\
\hline 1 & Roof & 1.18 \\
2 & Ceiling & 1.53 \\
3 & Wall & 1.11 \\
4 & Door \& Window & 2.70 \\
5 & Floor & 0.40 \\
6 & Foundation & 0.00 \\
7 & Utilities & 0.72 \\
\hline \multicolumn{2}{l}{ Total } & $\mathbf{7 . 6 4}$ \\
\hline \multicolumn{2}{r}{ Source: analysis results }
\end{tabular}

\subsection{Maintenance Cost}

After obtaining the volume of damage, the analysis was carried out to determine the maintenance and/or repairs. The analysis also includes a calculation of the cost of maintenance actions concerning to work price unit which is in the city of Salatiga. Standard reference price used based on the decision of the Mayor of Salatiga Number $900 / 348 / 2016$. Calculation of maintenance cost analysis process on the headmaster's space can be seen in table 6 .

Table 6. Analisis of Maintenance Cost of Principal's Office

\begin{tabular}{|c|c|c|c|c|c|c|c|}
\hline \multirow{2}{*}{ No } & \multirow{2}{*}{$\begin{array}{c}\text { Building } \\
\text { Component }\end{array}$} & \multirow{2}{*}{ Sub Building Component } & \multicolumn{3}{|c|}{ Damage } & \multicolumn{2}{|c|}{ Cost (Rp) } \\
\hline & & & Kind & Volume & Unit & Unit Price & Total \\
\hline \multirow[t]{3}{*}{1} & Roof & Roofing & - & 0 & $\mathrm{~m}^{2}$ & - & - \\
\hline & & Roof Frame & - & 0 & $\mathrm{~m}^{2}$ & - & - \\
\hline & & Roof gutter & $\begin{array}{c}\text { Weather } \\
\text { ed }\end{array}$ & 10 & $\mathrm{~m}^{2}$ & 123.000 & 1.180 .000 \\
\hline \multirow[t]{3}{*}{2} & Ceiling & Frame of ceiling & - & 0 & $\mathrm{~m}^{2}$ & - & - \\
\hline & & Ceiling cover & - & 0 & $\mathrm{~m}^{2}$ & - & - \\
\hline & & Paint & Faded & 24 & $\mathrm{~m}^{2}$ & 13.000 & 312.000 \\
\hline \multirow[t]{3}{*}{3} & Wall & Lintel and Columns & - & 0 & piece & - & - \\
\hline & & Brick Masonry wall & - & 0 & $\mathrm{~m}^{2}$ & - & - \\
\hline & & Paint & Faded & 80 & $\mathrm{~m}^{2}$ & 13.000 & 1.040 .000 \\
\hline \multirow[t]{2}{*}{4} & Door \& & Sills & - & 0 & piece & - & - \\
\hline & Window & Door & - & 0 & piece & - & - \\
\hline
\end{tabular}




\begin{tabular}{|c|c|c|c|c|c|c|c|}
\hline \multirow{3}{*}{ No } & \multirow{2}{*}{$\begin{array}{c}\text { Building } \\
\text { Component }\end{array}$} & \multirow{2}{*}{ Sub Building Component } & \multicolumn{3}{|c|}{ Damage } & \multicolumn{2}{|c|}{ Cost (Rp) } \\
\hline & & & Kind & Volume & Unit & Unit Price & Total \\
\hline & & Windows & - & 0 & piece & - & \\
\hline \multirow[t]{2}{*}{5} & Floor & Structure & - & 0 & $\mathrm{~m}^{2}$ & - & \\
\hline & & Floor cover & - & 0 & $\mathrm{~m}^{2}$ & - & \\
\hline \multirow[t]{2}{*}{6} & Foundation & The foundation & - & 0 & $\mathrm{~m}$ & - & \\
\hline & & Foundation beam & - & 0 & $\mathrm{~m}$ & - & \\
\hline \multirow[t]{2}{*}{7} & Utilities & Electrical & - & 0 & piece & - & \\
\hline & & $\begin{array}{l}\text { Installation of rain water \& } \\
\text { pedestrian walk in the } \\
\text { perimeter of the buildings }\end{array}$ & - & 0 & $\mathrm{~m}^{2}$ & - & \\
\hline
\end{tabular}

As well as on analysis to obtain the level of damage to building components, the analysis of the needs of repair costs also performed on the entire space in SMP Negeri 4 Salatiga. The analysis followed by pegging the maintenance cost of each component of the building. The analysis results can be seen in table 7 .

\begin{tabular}{clc}
\multicolumn{3}{c}{ Table 7. Maintenance Cost of SMP Negeri 4 } \\
\hline No & \multicolumn{1}{c}{$\begin{array}{c}\text { Building } \\
\text { components }\end{array}$} & Maintenace costs (Rp) \\
\hline 1 & Roof & 52.000 .000 \\
2 & Ceiling & 53.000 .000 \\
3 & Wall & 63.000 .000 \\
4 & Door \& Window & 56.000 .000 \\
5 & Floor & 27.000 .000 \\
6 & Foundation & 10.000 .000 \\
7 & Utilities & 0 \\
\hline \multicolumn{2}{c}{ Total }
\end{tabular}

Source: analysis results

Maintenance and rehabilitation prioritization in SMP Negeri 4 Salatiga devide in to three kinds:

a. School building maintenance based on level of damage

Based on the extent of the damage, maintenance and repair to school buildings are taken on the order of the greatest. So get the order of priority 1 to 6 , as in table 8 following:

Table 8. Maintenance and rehabilitation prioritization based on the extent of the damage

\begin{tabular}{clcc}
\hline No & Component & Damage Level (\%) & Priority \\
\hline 1 & Door & 2.70 & 1 \\
& Window & & \\
2 & Ceiling & 1.53 & 2 \\
3 & Roof & 1.18 & 3 \\
4 & Wall & 1.11 & 4 \\
5 & Utilities & 0.72 & 5
\end{tabular}




\begin{tabular}{clcc}
\hline No & Component & Damage Level (\%) & Priority \\
\hline 6 & Floor & 0.40 & 6 \\
7 & Foundation & 0.00 & 7 \\
\hline
\end{tabular}

Source: analysis results

b. Based on Maintenance Cost

The maintenance and rehabilitation of building components in school buildings can be seen in table 9 following:

Tabel 9. Priority of school building maintenance based on maintenance cost

\begin{tabular}{clcc}
\hline No & Component & Maintenance Cost (Rp) & Priority \\
\hline 1 & Wall & 63.000 .000 & 1 \\
2 & Door \& Window & 56.000 .000 & 2 \\
3 & Ceiling & 53.000 .000 & 3 \\
4 & Roof & 52.000 .000 & 4 \\
5 & Utilities & 27.000 .000 & 5 \\
6 & Floor & 10.000 .000 & 6 \\
7 & Foundation & 0 & 7 \\
\hline
\end{tabular}

Source: analysis results

c. Based on value of repairing

To determine the priority of maintenance, carried out an analysis of the extent of the deterioration and maintenance costs of each component of the building. The extent of deterioration includes the understanding that if the act of maintenance and rehabilitation have been done then will get the value of the repairing of any damage to the value of the component. Thus, the calculation and the analysis is influenced by the three value, namely the value of the level of damage, costs money, and the total available budget. The aims of this analysis are to get the maximum amount of the value of the improvements gained from the maintenance. The analysis was performed with attention to keeping costs and improvement of each component. The total cost of the repair/maintenance and shall not exceed the total budget available. The analysis using dynamic programming with Microsoft excel software for help. There is six stage of the analysis undertaken. The numbers are based on the components of the building suffered damage. Foundation components not included in the analysis because it is not damaged. Analysis of the results obtained is not the form of the order against building components but rather a package of maintenance activities against some components of the building. For more information, analysis results can be seen on table 10 the following: 
Table 10. Priority of School Building Components for Maintenance

\begin{tabular}{|c|c|c|c|c|c|}
\hline \multirow[b]{2}{*}{ No } & \multirow{2}{*}{$\begin{array}{c}\text { Building } \\
\text { Component }\end{array}$} & \multicolumn{2}{|c|}{ Implemented } & \multicolumn{2}{|c|}{ Not Implemented } \\
\hline & & $\begin{array}{c}\text { Damage } \\
\text { Level }\end{array}$ & $\begin{array}{c}\text { Maintenace } \\
\text { Cost }\end{array}$ & $\begin{array}{c}\text { Damage } \\
\text { Level }\end{array}$ & $\begin{array}{c}\text { Maintenance } \\
\text { Cost }\end{array}$ \\
\hline 1 & Wall & 2.70 & 63.000 .000 & - & - \\
\hline 2 & Door \& Window & 1.53 & 56.000 .000 & - & - \\
\hline 3 & Ceiling & - & - & 1.18 & 53.000 .000 \\
\hline 4 & Roof & - & - & 1.11 & 52.000 .000 \\
\hline 5 & Utilities & 0.72 & 27.000 .000 & - & - \\
\hline 6 & Floor & 0.40 & 10.000 .000 & - & - \\
\hline \multicolumn{2}{|c|}{ Jumlah } & 5.35 & 146.000 .000 & 2.29 & 105.000 .000 \\
\hline
\end{tabular}

\section{CONCLUSION}

From the above analysis, it can be concluded:

a. there are seven components of building analyzed in this research are roof, ceiling, wall, door \& window, floor, foundation, and utility;

b. From observations made in April - May 2017, the total damage that occurred in the building of SMP Negeri 4 Salatiga $7.64 \%$ (minor damage);

c. The foundation component is no damage, so its maintenance budget is $R p 0,-;$

$\mathrm{d}$. The available budget $\mathrm{g}$ for school building maintenance obtained by SMP Negeri 4 Salatiga in 2017 amounts to Rp 150,000,000, - (one hundred and fifty million rupiah), all of which are sourced from the Salatiga City Budgets;

e. Building Components in SMP Negeri 4 Salatiga which prioritized for maintenance there are four components, namely ceiling components, doors \& windows, floors, and utilities;

f. The amount of cost required to carry out the maintenance of 4 (four) components of the building amounted to Rp 146,000,000, - (one hundred forty-six million rupiah);

g. There is a remaining budget of $\mathrm{Rp} 4,000,000$, - (four million rupiah);

h. After maintenance, the level of damage will be reduced by $5.35 \%$ so that the level of damage to the building of SMP Negeri 4 Salatiga to $2.29 \%$.

\section{ACKNOWLEDGEMENTS}

The author acknowledges the contribution of the city government of Salatiga in providing data. The support received during field observation is highly appreciated.

\section{REFERENCES}

[1] Ahmed Z and Younas I 2011 A Dynamic Programming based GA for 0-1 Modified Knapsack Problem, International Journal of Computer Applications (0975 - 8887)Volume 16- No.7, February 2011, Pakistan.

[2] Arista WM 2013 Penerapan Algoritma Greedy dan Dynamic Programming pada 
Permasalahan Integer Knapsack, Skripsi, Jurusan Matematika Fakultas Matematika dan Ilmu Pengetahuan Alam Universitas Jember.

[3] Bellman R 1954 The Theory Of Dynamic Programming, P-550, California.

[4] Bertsimas D dan Demir R 2002 An Approximate Dynamic Programming Approach to Multidimensional Knapsack Problems, MANAGEMENT SCIENCE (C) 2002 INFORMS, Volume 48,No. 4, April 2002 pp. 550-565.

[5] Boyer V, El Baz D, and Elkihel Moussa Solution of Multidimensional Knapsack Problem via Cooperation of Dynamic Programming and Branch and Bound, LAAS-CNRS, Universite de Toulouse, 7, Avenue du Colonel Roche-31077 Toulouse Cedex 4.

[6] Chandra A 2005 Pemecahan Masalah Pemuatan Barang dengan Dynamic Programming di PT. Krista Jaya Indosol, Skripsi, Jurusan Teknik Industri Universitas Bina Nusantara, Jakarta.

[7] Cahn E 2014 Building Maintenance Strategy: A Sustainable Refurbishment Perspective, Universal Journal of Management 2(1): 19-25, 2014 DOI: 10.13189/ujm.2014.020103, http://www.hrpub.org.

[8] Direktorat Jenderal Cipta Karya, 2006, Pedoman Persyaratan Teknis Bangunan Gedung, Peraturan Menteri Pekerjaan Umum Nomor 29/PRT/M/2006, Direktorat Jenderal Cipta Karya Departemen Pekerjaan Umum Republik Indonesia.

[9] Direktorat Jenderal Cipta Karya, 2008, Pedoman Pemeliharaan Bangunan Gedung, Peraturan Menteri Pekerjaan Umum Nomor 24/PRT/M/2008, Direktorat Jenderal Cipta Karya Departemen Pekerjaan Umum Republik Indonesia.

[10] Direktorat Jenderal Cipta Karya, 2010, Pedoman Pedoman Teknis Pemeriksaan Berkala Bangunan Gedung, Peraturan Menteri Pekerjaan Umum Nomor 16/PRT/M/2010, Direktorat Jenderal Cipta Karya Departemen Pekerjaan Umum Republik Indonesia.

[11] Eduardo Pombal Luila 2008 Multicriteria Knapsack Problem - Algorithmic Aspects and Computer Implementation, Instituto Superior Tecnico, Universade Tecnica de Lisboa.

[12] Iveta Puḳitea and Ineta Geipeleb 2017 Different Approaches to Building Management and Maintenance Meaning Explanation, Procedia Engineering 172 ( 2017 ) 905 - 912, Available online at www.sciencedirect.com.

[13] Lampiran Keputusan Walikota Salatiga Nomor 900/348/2016 tentang Standardisasi Indeks Biaya Bidang Cipta Karya Tahun Anggaran 2017.

[14] Peraturan Menteri Pendidikan dan Kebudayaan Republik Indonesia Nomor 57 Tahun 2011 tentang Petunjuk Teknis Penggunaan Dana Alokasi Khusus (DAK) Bidang Pendidikan Tahun Anggaran 2012 untuk Sekolah Menengah Pertama.

[15] Peraturan Menteri Pendidikan dan Kebudayaan Republik Indonesia Nomor 9 Tahun 2015 tentang Petunjuk Teknis Penggunaan Dana Alokasi Khusus Bidang Pendidikan Tahun Anggaran 2015. 
[16] Peraturan Direktur Jenderal Pendidikan Dasar Nomor 144/C/KP/2015 Tahun 2015 tentang Petunjuk Pelaksanaan Dana Alokasi Khusus Bidang Pendidikan Dasar Tahun Anggaran 2015.

[17] Surjawan DJ dan Susanto I 2015 Aplikasi Optimalisasi Muat Barang dengan Penerapan Algoritma Dynamic Programming pada Persoalan Integer Knapsack, Jurnal TeknikInformatika dan Sistem Informasi Volume 1 Nomor 2, Agustus 2015 ISSN: 2443 - 2229, Bandung.

[18] Sutikno 2009 Sistem Penentuan Sekala Prioritas Pemeliharaan Bangunan Sekolah Tesis Magister Teknik Sipil Konsentrasi Teknik Rehabilitasi dan Pemeliharaan Bangunan Sipil Program Pascasarjana Universitas Sebelas Maret Surakarta.

[19] Toth P 1979 Dynamic Programming Algorithms for the Zero-One Knapsack Problem, Computing 25, 29 45 (1980), Bologna.

[20] Wijayanti AR, SA Kristiawan, Syafii 2015 Skala Prioritas Pemeliharaan Gedung Kantor Balai Pelatihan Konstruksi Wilayah V Jayapura Jurnal Teknik Sipil Magister Teknik Sipil Universitas Sebelas Maret Vol. III No. 1 - Maret 2015 ISSN: 2339 - 0271, Surakarta.

[21] http://web.mit.edu/15.053/www/AMP-Chapter-11. 